\title{
Service Learning on Inclusive Design: Adaptive Home for Wheelchair-Using Persons with Disabilities
}

Gunawan Tanuwidjaja ${ }^{1, *}$, Felicia Lisandra $^{1}$, Agnes Magdalena ${ }^{1}$, Josephin Martina Negara $^{1}$, and Arina Hayati $^{2}$

${ }^{1}$ Architecture Program, Petra Christian University, Jl. Siwalankerto No.121-131, Surabaya 60236, Indonesia

${ }^{2}$ Architecture Department, Institute Technology of Sepuluh November (ITS), Jl. Raya ITS, Surabaya 60111, Indonesia

\begin{abstract}
More than 1000000000 people in the world live with disabilities, and 200000000 among them experience heavy functioning difficulties. Persons with Disabilities (PwDs) usually have limited economic participation, faced poverty and limited access to housing. Service Learning Program in Architecture Department (Inclusive Design Course) was created to answer the Persons with Disabilities (PwDs) needs. The course was supported by UBCHEA (https://unitedboard.org/) for the program of Service Learning of Inclusive Design for Homes and Schools in Surabaya and Bandung: Participatory Design and Campaign. It started with accessibility evaluation at PwDs' residences (wheelchair users) in Surabaya. Simulation as PwDs in Petra Campus was also conducted to create empathy to wheelchair users. Later on, an inclusive-and-universal design was proposed. Three participatory workshops in Surabaya and Bandung were conducted to review it. The new design was produced to cater the wheelchair users. In conclusion, role play and participatory design process was the important key points of the program's success.
\end{abstract}

Key words: Accessibility, disability, home and living design, inclusive design

\section{Introduction}

\subsection{Background}

As in [1] highlighted that more than 1000000000 people in the world live with different disabilities, of whom nearly 200000000 among them experience heavy functioning difficulties. Persons with Disabilities (PwDs) normally had poorer health outcomes, lower education achievements, less economic participation and higher rates of poverty than other people. Therefore, they faced difficulties to access the affordable and accessible housing.

\footnotetext{
*Corresponding author: gunte@petra.ac.id gunteitb2012@gmail.com
} 
A Service Learning Program on Inclusive Design was created in the Architecture Program to answer the needs of Persons with Disabilities (PwDs) especially the housing aspect. UBCHEA (https://unitedboard.org/) supported the course in the program namely Service Learning of Inclusive Design for Homes and Schools in Surabaya and Bandung: Participatory Design and Campaign.

Housings for wheelchair users (Person with Disabilities/PwDs) were also observed generally by Hayati. The micro-house concept was widely present because of the PwDs' limited economical capacity and the expensive land price in Surabaya. The micro-house was accessible by wheelchair users in general area (such as living room and family room), but some other areas of the house are only visitable by them because of its spatial limitation.

\subsection{Literature Review}

Universal Design Standards, Inclusive Design and also Collaborative or Co-Design were discussed in several papers by Persson, et al. [2]; Bühler [3]; and Pirinen [4] as the methods to produce a more inclusive design in Architecture.

In [5] explains that Universal Design is applied to create a more viable building and community for all. Five main aspects of Universal Design are sustainability, marketability, affordability, security, and social interaction. They are summarized as home visitability. Visitability attempted to make a house more accessible through these three basic requirements: One zero-step entrance (either the front door, sideway door, or backdoor), 32 in $(810 \mathrm{~mm})$ doorway clearance and the corridors' clear width shall be at least 36 in $(910$ $\mathrm{mm}$ ), and half of the bathroom has to be available in the main/ground floor. Some elements were standardized to help people with mobility impairment to either visit or live in the house.

First, the Entrance Unit (1006.2): at least one entrance unit should be on circulation path complying Section 1006.5 (Circulation Path) from a public street or sidewalk, dwelling unit driveway, or garage.

Connected and Interior Spaces (1006.3 \& 1006.4): a circulation path (as complied on Section 1006.5) should connect the entrance unit located on the circulation path to the following spaces: an entrance level toilet/bathroom, an additional habitable space with an area $70 \mathrm{~m}^{2}$ minimum, and food preparation area when provided on entrance level (complying with Section 1006.7.)

Circulation Path (1006.5), The Components (1006.5.1): A circulation path should include one or more of the following elements, including: walking surface with a slope not steeper than 1:20, doorways, ramps, escalators, and elevators. Ramps (1006.5.4): Ramps should comply with Section 405.

Toilets or Bathrooms (1006.6): Toilets or bathrooms should comply with section 1006.4 (Interior Space) and cover the following features, namely lavatory and toilet, reinforcement and space clearance for future grab bars installation as wide as $455 \mathrm{~mm}$ (18 in) from the centerline of the toilet, lavatory $(380 \mathrm{~mm} / 15$ in from the centerline of the toilet), space clearance at the toilet should meet/exceed minimum requirements.

Food Preparation Area (1006.7): When located at entrance level, the food preparation area should include a sink, cooking appliances, and fridge. Clearances between opposing cabinets, countertops, appliances, and walls within the food preparation area should be wider than 40 in $(1015 \mathrm{~mm})$.

Lighting Controls and Receptacle Outlets (1006.8): The centerline of receptacle outlets and operable control parts should be placed at least 15 in $(380 \mathrm{~mm})$ and not more than 48 in $(1220 \mathrm{~mm})$ above the finishing floor. 
The standard accessible designs are vital in designing a home for people with disability. However, the application of the designs should also consider the needs of the users, social and economic conditions, and the construction of the existing buildings. These standards were also supported by Nickson [6] and Pike, et.al. [7].

On the other hand, some standard were prescribed by D'Souza, et.al. [8] on knee and toe clearances for wheelchair users. Adequate clearance space under table or tops to the floor was important. Therefore, wheelchair users can approach it close enough without any obstacles. Such clearance space was critical when there are elements like bathroom sinks, kitchen countertops etc.

\section{Methodology}

The Service Learning Course on Inclusive Design was started with literature review of the wheelchair users. The documentation of the Persons with Disabilities (PwDs) spectrum in schools (including teachers with disabilities, students with disabilities) was started with database and interviews. Unfortunately, only some PwDs willing to answer the questions in the interviews. The PwDs were reluctant to be documented because of their sensitivity towards the issue. They would like to participate during the process but rejected the data collection.

After understanding the universal design standard, the students were guided to document and evaluate the accessibility of the wheelchair user's residence (Mr. Abdul Syakur). He was a teacher in Special School for Children with Disability (YPAC) in Surabaya. Unfortunately, his home was found as partially unaccessible (for PwDs), therefore it should be redesigned.

Thirdly, the PCU students were asked to simulate as PwDs in Petra to empathize with the wheelchair users. Later on, a design was prepared based on the inclusive and universal design theories. Three participatory design workshops in Surabaya and Bandung were conducted to review the design. And that new design was produced to cater the accessibility of Mr Syakur that represents the PwDs with wheelchair. In conclusion, role play and participatory design process was the important key points of the program's success.

Lastly, Creative Campaign for Universal Design application in Surabaya were conducted, comprising of: the distribution of Living in Dignity book which contained PwDs homes design, bulletin of PwDs rights, artistic event and exhibition. The Creative Campaign were conducted in Petra Christian University and in a Surabaya Memory event in Grand City Mall. The events were held with the support of General Education Department (Departemen Mata Kuliah Umum/DMU) and Petra Christian University Library (the Library@Petra). The campaign happened to be successful in promoting the rights of Persons with Disabilities (PwDs) especially in housing and education sector to Surabaya's people in general and PCU's Community specifically [9]. 


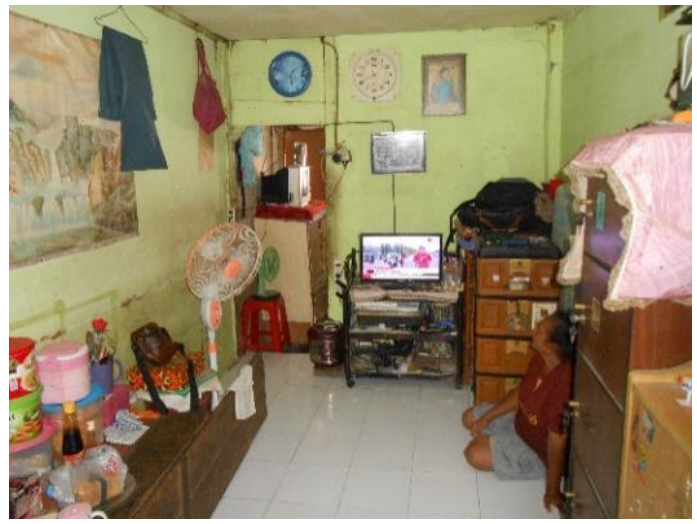

Fig. 1. Accessibility in PwDs home.

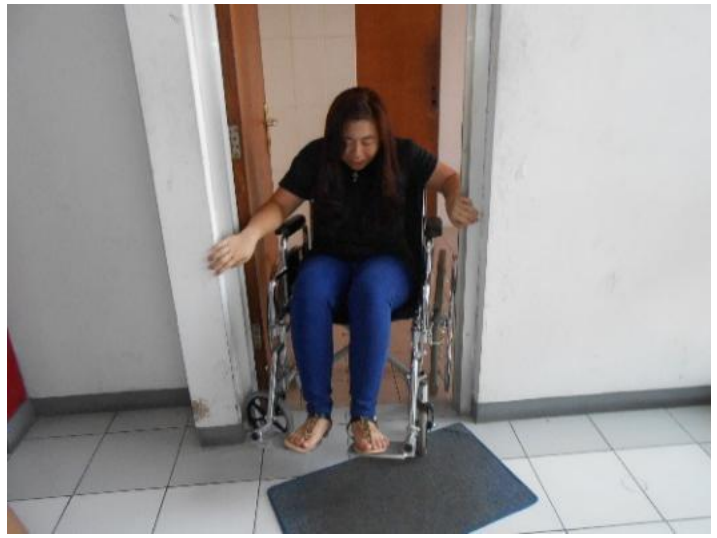

Fig. 2. Students' simulation as PwDs.

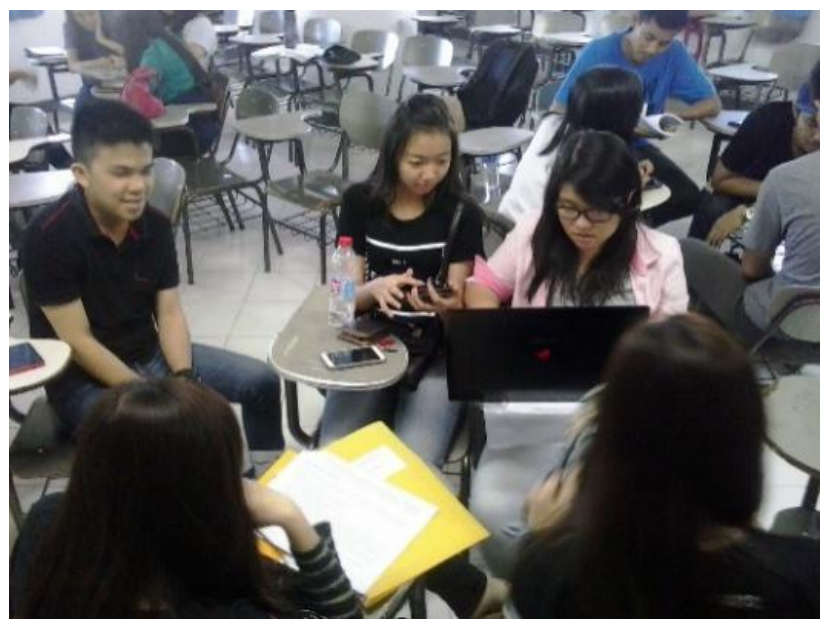

Fig. 2. Students' design process. 


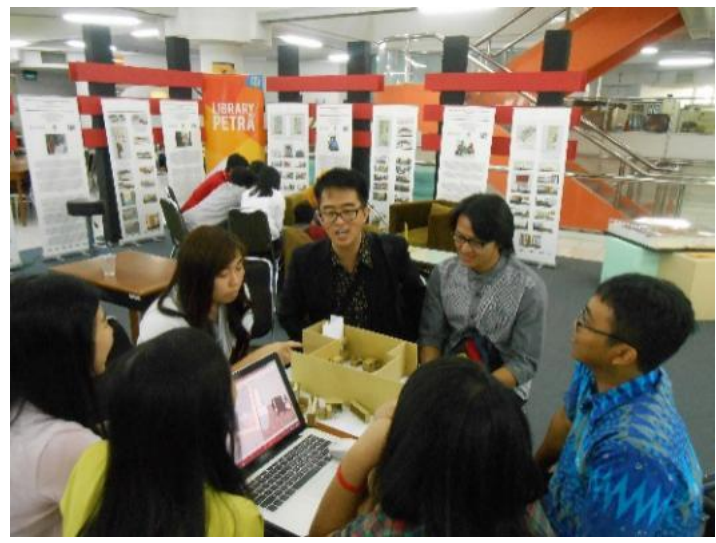

Fig. 4. Discussion process in the participatory design workshop.
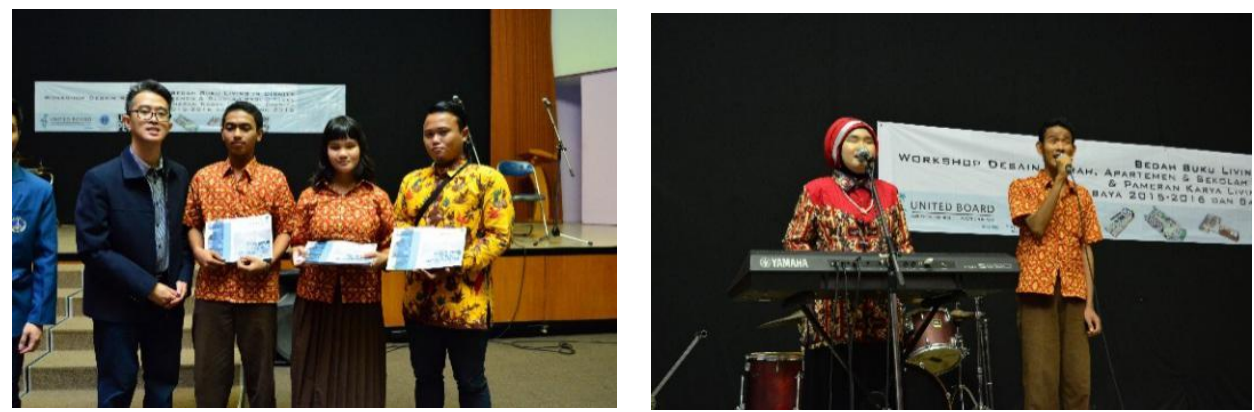

Fig. 5. The creative campaign and exhibition for PwDs rights.
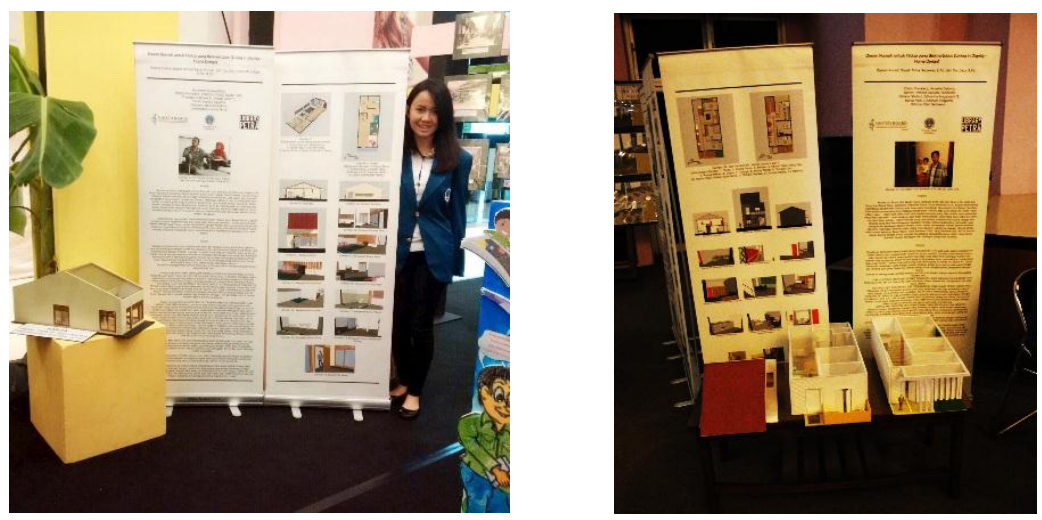

Fig. 6. The creative campaign and exhibition for PwDs rights.

\section{Results and discussion}

The results of the design prescribed a $51 \mathrm{~m}^{2}$ home (on $91 \mathrm{~m}^{2}$ lot). The house that became the case study's object was adopted from a housing in the suburban area of Sidoarjo which was developed by Jaya Land. The PwDs' homes were normally located around this area because of its affordable land price.

The proposed home consisted of a front garden, front porch, living room, master bedroom, child's bedroom, kitchen and dining room, bathroom and a backyard. The house could accommodate four persons (Mr. Abdul Syakur, his wife, and his two children). The 
smaller house was prescribed in responds to the needs of PwDs who have a limited economic capability.

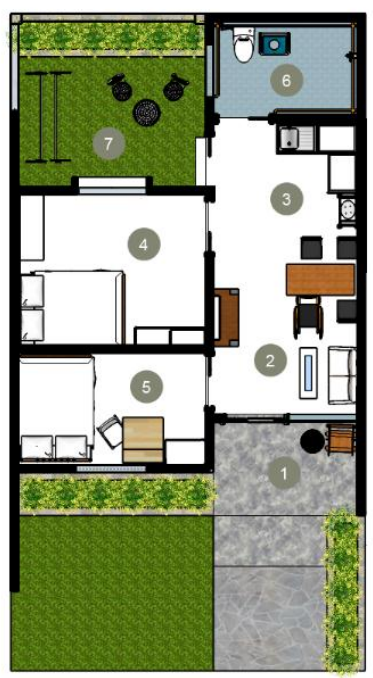

(Explanation: 1. Parking area, 2. Living room, 3.Dining Area and Kitchen, 4. Master Bedroom, 5. Children Bedroom, 6.Bathroom, 7. Front and Backyard)

Fig. 7. Floor plan.

Design principles were implemented to the wheelchair user's house, according to [10] such as:

i) User Centered principle was implemented through interviews, discussions, and workshops with Mr. Abdul Syakur.

ii) Equitable but Reasonable Use principle was implemented with the steeper leveling and accessible pathways and doors. Several ramps were provided with the level of 1:20, which means every $10 \mathrm{~cm}$ height difference, $200 \mathrm{~cm}$ length ramp was provided. The 100 $\mathrm{cm}$ width ramp was provided. The furniture were designed for wheelchair users' reaching range. Additional wheelchair rotation space were provided in the kitchen and tables. The windows' height were adjusted from $0.6 \mathrm{~m}$ to $2.1 \mathrm{~m}$ to facilitate wheelchair users viewing range.

iii) Simple and Intuitive Use principle was implemented by the linear circulation space, to provide a simple and easy accessibility for wheelchair users.

iv) Low Physical Effort principle was implemented by the selection of lightweight materials for sliding doors. Besides that, the furnitures such as dining tables, kitchen tables, and desks were designed with consideration of the wheelchair users' reaching range. The tables' height were designed to be $80 \mathrm{~cm}$, while the bed was designed with $50 \mathrm{~cm}$ height. The wardrobe for wheelchair users were designed ranging from $0.2 \mathrm{~m}$ to $1.2 \mathrm{~m}$ in its height. Meanwhile the rest of the storage could be used for other nondisability users. The windows were designed with $60 \mathrm{~cm}$ height for wheelchair users's comfortable viewing activity. And the sockets and switches were provided on $1.1 \mathrm{~m}$ height. Bathroom's railing, adjustable shower head, water tap were additional features that were aligned with this principle.

v) Prohibition of Usage Error principle was implemented with the furnitures, which was designed with rounded edges. Anti-slip ceramics, railings in the bathroom, as well as the steady furniture were also taken into account.

Detailed explanation of the design were prescribed in the following paragraphs. 
The front garden (size of $4 \mathrm{~m}$ by $3 \mathrm{~m}$ ) was provided to ensure the cooling effect within the home. Meanwhile, $3.85 \mathrm{~m}$ by $3 \mathrm{~m}$ backyard was also provided to ensure the home's cross ventilation, while also providing space for relaxing activities and drying clothes.

The house's porch and parking lot $(3 \mathrm{~m}$ by $5 \mathrm{~m})$ was also established. The front porch was designed with anti-slip natural stone. There are no elevation difference inside the house. Ten-cm level difference was present between interior and the parking lot, and it was facilitated with ramp $(1: 20)$.

Open-plan Family Room was designed to facilitate the clear pathway. The linear circulation with $1.10 \mathrm{~m}$ width was created for wheelchair user movement. The room was also designed with anti-slip ceramics. Height-adjustable furnitures with $80 \mathrm{~cm}$ height and rounded edges were provided to ensure users safety. Spaces for turning wheelchair were also provided.

The dining area was equipped with wooden dining table (with the dimension of $1 \mathrm{~m} \times$ $1.3 \mathrm{~m}$ by $82 \mathrm{~cm}$ height). The television was placed close to the dining table for users' social interaction. Because of the wheelchair users' limited reach, switches and sockets (with protectors) were placed at $1.1 \mathrm{~m}$ height. And the switches were located in the central area near master bedroom for easier lighting control.

In the kitchen area, the kitchen set for storing cooking utensils was provided for non disability persons. But all kitchen tabletop was designed to be accessible by the PwDs with its $80 \mathrm{~cm}$ height, rounded edges, and there are also spaces for wheelchair users. The Lshaped kitchen was selected for more spacious space and wheelchair accessibility. The kitchen was located close to the backyard, in order to create a better ventilation and lighting. Exhaust fan was also prepared to extract cooking fumes and smokes.

The master bedroom were designed with the size of $3.15 \mathrm{~m}$ by $3.85 \mathrm{~m}$, and its circulation corridor was $1.5 \mathrm{~m}$. The room were equipped with a bed, wardrobe, and a working desk. The light, $90 \mathrm{~cm}$ width wooden sliding door was also provided here. The door knob with $90 \mathrm{~cm}$ height was catered for the accessibility of wheelchair users. The antislip ceramic was also applied in the room. Besides that, the window (which has lower height) was provided to facilitate the wheelchair users so they can enjoy the backyard view.

The Children's Bedroom was set with the size of $2.3 \mathrm{~m}$ by $3.85 \mathrm{~m}$. There is no difference in elevation level from the living room to the child's bedroom. Similar light, wooden sliding door with a door knob was also provided. The furnitures in this room were a bed, a wardrobe and a desk. Windows and ventilations were provided for air circulation and natural lighting of the room.

The bathroom was provided with total area of $2 \mathrm{~m}$ by $3 \mathrm{~m}$. It was designed to be divided into two sections: the dry area and the wet area (shower area). Clothes and towel hangers were located near the door. There was a $36 \mathrm{~cm}$ ramp for $3 \mathrm{~cm}$ level difference between the bathroom and external areas. Besides that, a light, $1 \mathrm{~m}$ width plastic sliding door was provided in the bathroom. Among the bathroom perimeter, railings were installed with 70 $\mathrm{cm}$ height. The edge of the railings were designed with rounded shapes. The light switch for the toilet was placed outside of the bathroom. High window as the sidelight was also provided to facilitate healthier air quality. The wheeled shower chair was also provided (40 $\mathrm{cm}$ by $40 \mathrm{~cm}$ ). Meanwhile, the shower head was designed to be adjustable between $1.1 \mathrm{~m}$ to $2.1 \mathrm{~m}$. The shower could be controlled with lever tap. 


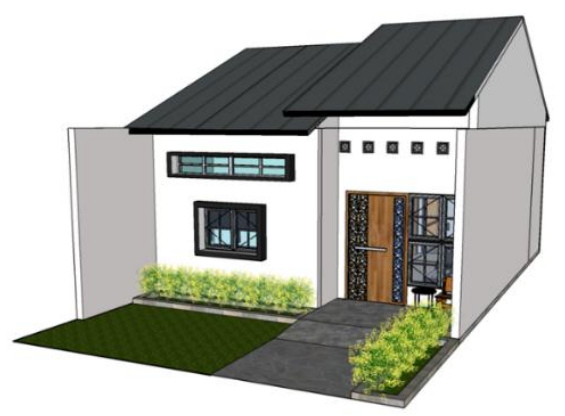

Fig. 8. Front perspective of the home.

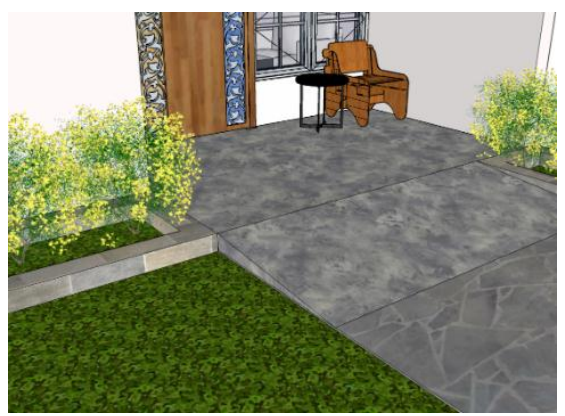

Fig. 9. Perspective of front porch with 1:12 ramp and anti-slip flooring.

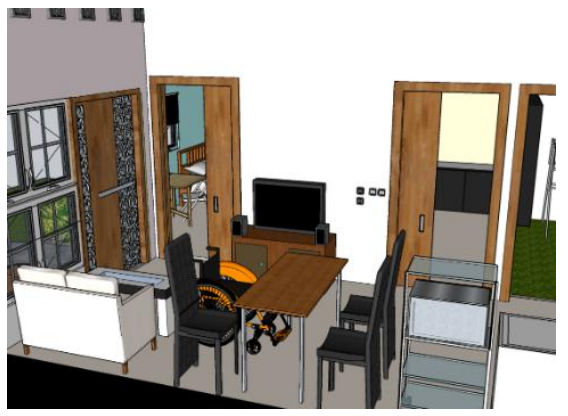

Fig. 10. The living room, dining area, with the $1.2 \mathrm{~m}$ clear width passageway and sliding door.

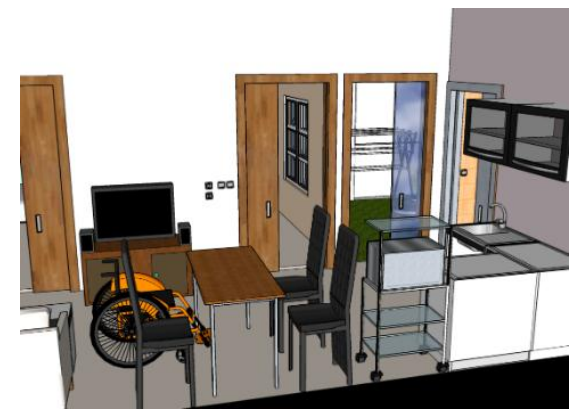

Fig. 11. The living room, dining area and kitchen area. 


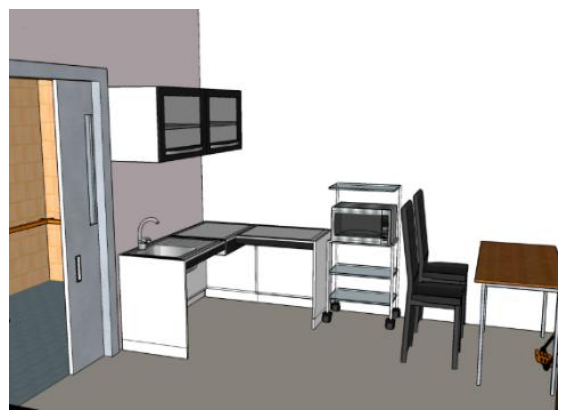

Fig. 12. The kitchen area, with clearance for wheelchair, anti-slip flooring, reachable sink and table top.

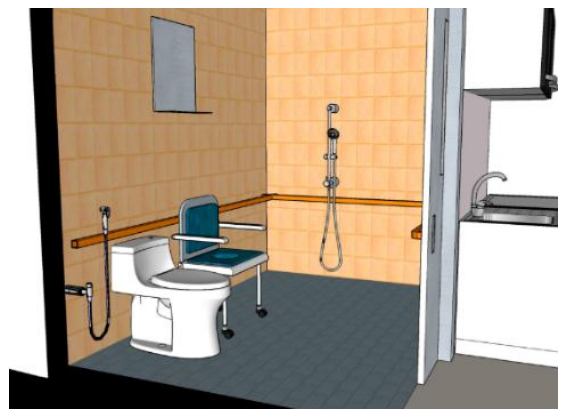

Fig. 13. The bathroom, with sliding door, railing, anti-slip flooring, bathing chair and sitting toilet.

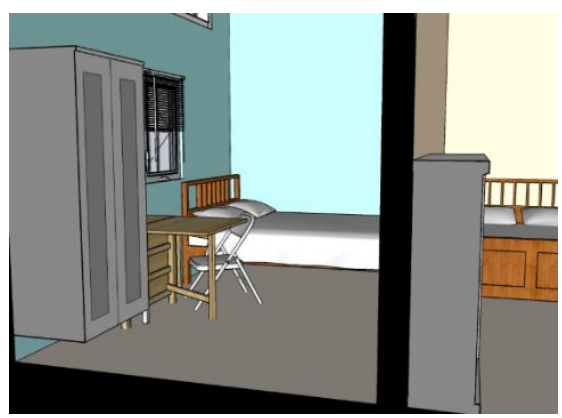

Fig. 14. Children's bedroom that only partially accessible by the PwDs because of the limited space.

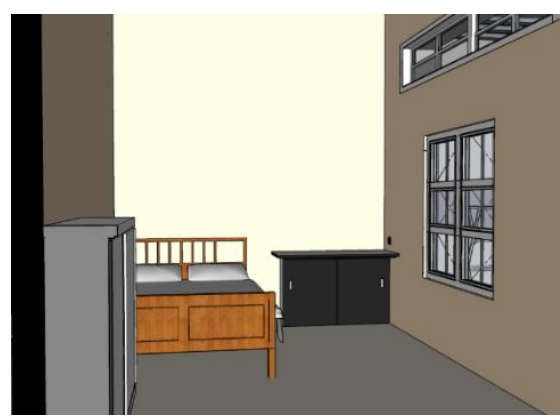

Fig. 15. The fully-accessible master bedroom. 


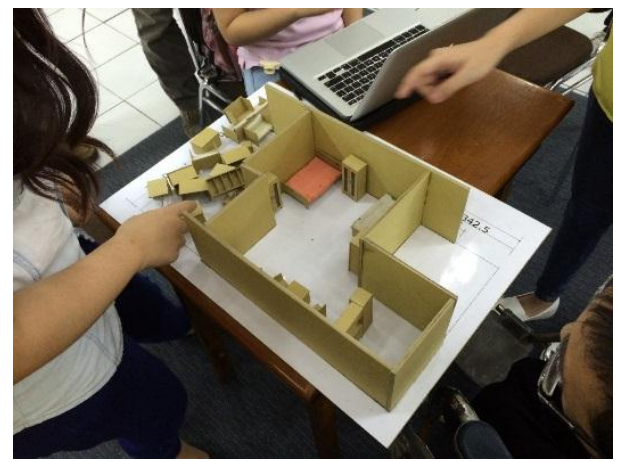

Fig. 16. The Architectural Model provided for discussion.

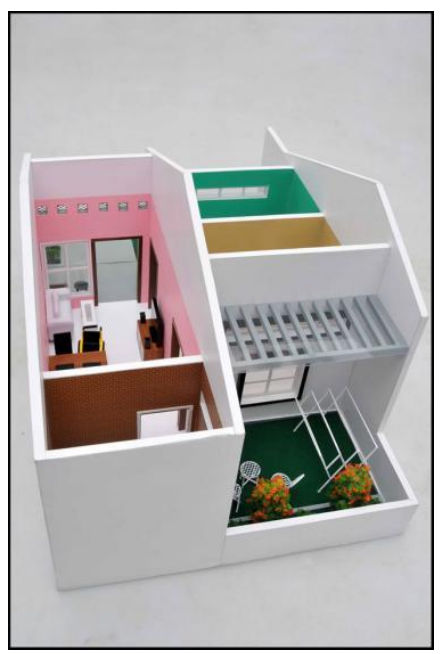

Fig. 17. Professional architectural model for exhibition.

The wheelchair user's home design showed that visitable home could be designed within limited land area. With a well-planned material selection and innovation, this home design also meant to be more affordable for the PwDs family to acquire.

\section{Conclusion}

Housing for Persons with Disabilities issue became mandatory because of Indonesian Act no 8 Year 2016, on Persons with Disabilities (UU no 8 tahun 2016, tentang Penyandang Disabilitas) [11] was gazetted. The regulation actually ensured the rights for accessible housing in Section 8 on privacy rights of PwDs (Pasal 8 Hak tentang privasi untuk Penyandang Disabilitas), Section 23 on rights for PwDs to live indepently (Pasal 23 tentang Hak hidup secara mandiri dan dilibatkan dalam masyarakat), and Section 97 \& 98 on infrastructure provision especially for housing for PwDs (Pasal 97 tentang Penyediaan infrastruktur termasuk bangunan gedung atau hunian yang aksesibel). Therefore the accessible housing provision should be supported by Municipality and Provincial Government, with collaboration from all stakeholders. The existing regulation also could be adjusted to the latest universal design standards and researchs adopted from developed countries, meanwhile innovation on design and material application should be pursued for affordability aspect. 
The authors would like to thank:

i) UBCHEA (United Board for Christian Higher Education in Asia) for supporting the research entitled Service Learning of Inclusive Design for Homes and Schools in Surabaya and Bandung: Participatory Design and Campaign.

ii) Library@Petra (Library of Petra Christian University or PCU), Surabaya Memory, the DMU (General Education Department of PCU), Visual Communication Design Program Study of PCU, Architectural Program Study of PCU.

iii) External partners such as Institute Technology of Tenth of November (ITS), Institute Technology Bandung (ITB), School of Architecture, Planning and Policy Making, Department of Architecture, YPAB Surabaya (The Educational Foundation of Blind Children), YPAC Surabaya (The Educational Foundation of Disabled Children), BILIC (Bandung Independent Living Center), Gerkatin Jawa Barat (The Movement of The Deaf Person in Indonesia, West Java Section), and Surabaya Riverside-Villages' Residents Association (PWSS/ Paguyuban Warga Strenkali Surabaya).

iv) Special thanks were given to Mr. Abdul Syakur S.E.. and also to other resource persons such as: Mr. Ahmad Fauzi M.Hum., Mrs, Lilik Ghoniyah Sofyan M.Ed., Ms. Paulina Mayasari S.Sn., Mr. Tutus Setiawan S.Pd. and Mrs. Desy S.Pd., Mr. Warsito, Mr. Gatot Subroto, and Mr. Hariyono Karno.

v) The Service Learning's Team: Dr. ir. Joyce Marcella Laurens, M.Arch., IAI, Ir. I Gusti Nyoman Sulendra, Erandaru, ST. MSc.

vi) The Service Learning's Students: Jocelin Marchelina, Clara Cynthia W, Yohan Surya P, and Estherina Gazali

\section{References}

1. WHO, World Bank. World report on disability [Online] from www.who.int/disabilities/world_report/2011/report.pdf (2011). [Accessed on 10 November 2017]

2. H. Persson, H. Åhman, A.A. Yngling, and J. Gulliksen. Universal Access in the Information Society, 14, 4:505-526 (2015). https://link.springer.com/article/10.1007/s10209-014-0358-z

3. C. Bühler. Universal Access in the Information Society, 1, 2:85-90 (2001). https://link.springer.com/journal/10209/1/2/page/1

4. A. Pirinen. International Journal of Design, 10, 3:27-42 (2016). http://www.ijdesign.org/index.php/IJDesign/article/view/2575/749

5. E. Steinfeld, J. White. Visitability an inclusive design approach of housing. New York: Center for Inclusive Design \& Environmental Access (2009).

6. G. Nickson. Housing, Care and Support, 8, 1:29-32 (2005). https://www.emeraldinsight.com/doi/abs/10.1108/14608790200500007

7. J. Pike, M. Stineman. Journal of Rehabilitation Research and Development, 38, 1, S54, (2001)

8. C. D’Souza, J. White, E. Steinfeld, V. Paquet. Knee and toe clearances for wheeled mobility users [Online] from http://udeworld.com/knee-and-toe-clearances-forwheeled-mobility-users (2009). [Accessed in 26 September 2017]

9. G. Tanuwidjaja, J.M. Laurens, I.G.N. Sulendra, Erandaru. Service learning of inclusive design for homes and schools in Surabaya and Bandung: participatory design and campaign. Surabaya: Petra Christian University (2016). [unpublished].

10. G. Tanuwidjaja. Desain rumah untuk hidup yang bermartabat [Living in dignity home design]. Surabaya: Program Studi Arsitektur, Universitas Kristen Petra (2015). [in Bahasa Indonesia] http://repository.petra.ac.id/17681/ 
11. Republik Indonesia. UU no 8 tahun 2016 tentang penyandang disabilitas [Act no 8 years 2016 on persons with disability] [Online] from http://peraturan.go.id/uu/nomor8-tahun-2016.html (2016). [Accessed on 5 Oktober 2017]. [in Bahasa Indonesia]. 